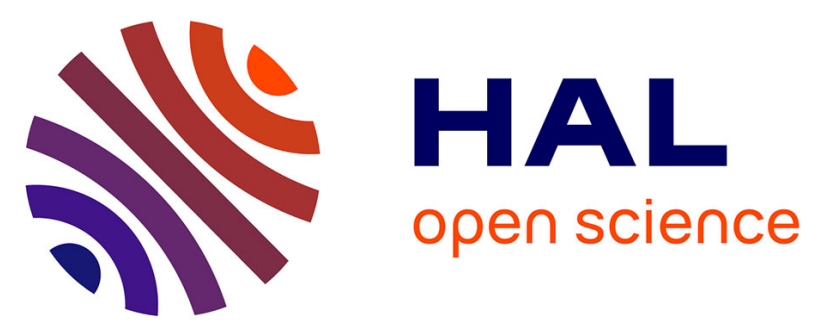

\title{
Contribution of geophysical surveys to the study of fine grained lacustrine sediments. Application to the Sarliève marsh (Massif Central, France)
}

Florent Hinschberger, Agathe Fourmont, Jean-Jacques Macaire, Jean-Gabriel Bréhéret, Roger Guerin, Jean-Paul Bakyono

\section{To cite this version:}

Florent Hinschberger, Agathe Fourmont, Jean-Jacques Macaire, Jean-Gabriel Bréhéret, Roger Guerin, et al.. Contribution of geophysical surveys to the study of fine grained lacustrine sediments. Application to the Sarliève marsh (Massif Central, France). Bulletin de la Société Géologique de France, 2006, 177 (6), pp.311-322. 10.2113/gssgfbull.177.6.311 . hal-02310142

\section{HAL Id: hal-02310142 \\ https://hal.science/hal-02310142}

Submitted on 15 Oct 2019

HAL is a multi-disciplinary open access archive for the deposit and dissemination of scientific research documents, whether they are published or not. The documents may come from teaching and research institutions in France or abroad, or from public or private research centers.
L'archive ouverte pluridisciplinaire HAL, est destinée au dépôt et à la diffusion de documents scientifiques de niveau recherche, publiés ou non, émanant des établissements d'enseignement et de recherche français ou étrangers, des laboratoires publics ou privés. 


\title{
Contribution of geophysical surveys to the study of fine grained lacustrine sediments. Application to the Sarliève marsh (Massif Central, France)
}

\author{
FLORENT HINSCHBERGER ${ }^{1}$, AgATHE FOURMONT ${ }^{1}$, JEAN-JACQUes MACAIRE ${ }^{1}$, JEAN-GABRIEl BREHERET ${ }^{1}$, \\ ROGER GUERIN ${ }^{2}$ and JEAN-PAUL BAKYONO ${ }^{1}$
}

\begin{abstract}
Key words. - Geophysics, Electric and electromagnetic survey, EM31, Lacustrine sediments, Sarliève marsh, Lateglacial, Holocene.
Abstract. - This paper presents the results of a geophysical survey which was performed in the Sarliève marsh, located in the north of the Massif Central (France). The studied area corresponds to an ancient lake filled with $6 \mathrm{~m}$ of Lateglacial to historic sediments. The numerous cores and excavations previously performed in basin areas show the presence of thick fine grained and carbonated lake deposits. The mineralogical study of these deposits allows us to distinguish two main types of formations, which differ in their composition and origin. In the lower part of the sedimentary filling, the SDLF formation is generally characterized by abundant chalky and dolomitic layers, probably formed by chemical precipitation in an endoreic environment. It was found only in the distal (or depocenter) parts of the ancient lake. The upper part of the filling corresponds to calcitic clayey silty sediments (CF), mainly of detrital origin. They can be found both in the distal and proximal parts of the ancient lake. In order to precise the geometry of the marsh sedimentary filling and to discriminate between these two fine grained sediment types (SDLF and CF), an electromagnetic survey was carried out using an EM31 conductivity meter. It was completed by 16 electrical soundings performed within the marsh.

The electromagnetic survey enables us to draw a large-scale conductivity map, which highlights the presence of a highly conductive zone (HCZ) in the central part of the marsh, more pronounced in the south. The HCZ is bordered by more resistive and heterogeneous fields, where conductive structures are visible. We show that there is no clear correlation between the measured conductivity and the total lacustrine sediment thickness. However, the HCZ is related to the distal parts of the ancient lake, locally identified from borehole data. In the corresponding sedimentary filling, the SDLF formation appears as a very low resistive layer (about $1.2 \Omega \mathrm{m}$ ) on the electrical soundings. It explains the high conductivity of the distal lacustrine sediments. We finally combine the cores and the geophysical data to estimate the spatial extent and the volume of the SDLF formation of the whole marsh. This study shows that geophysics can contribute to distinguish, in a globally homogeneous fine grained sedimentary filling (carbonated clayey silts), lacustrine sediments formed in very different contexts, one as chemical precipitation, the other of detrital origin.
\end{abstract}

\section{Apport des méthodes géophysiques à l'étude de sédiments lacustres à granulométrie fine. Application au marais de Sarliève (Massif Central, France)}

\begin{abstract}
Mots clés. - Géophysique, Méthodes électrique et électromagnétique, EM31, Sédiments lacustres, Marais de Sarliève, Tardiglaciaire, Holocène.

Résumé. - Dans cette note, nous présentons les résultats d'une prospection géophysique réalisée dans le marais de Sarliève, situé au sud de Clermont-Ferrand, dans le Massif central. La zone étudiée correspond à un ancien lac d'une superficie d'environ $5 \mathrm{~km}^{2}$, qui a été drainé et asséché au cours du XVII e siècle. Les nombreux forages carottés réalisés dans le marais ont montré la présence d'un remplissage sédimentaire épais (maximum $6 \mathrm{~m}$ ) allant du Tardiglaciaire à l'époque historique. Des zones de deltas et de bassins lacustres ont été identifiées. Dans les zones de bassins lacustres, les sédiments sont argilo-silteux et carbonatés, et d'apparence assez homogène. Deux grands types de formations sédimentaires y ont été distingués d'après leur composition minéralogique et leur origine. Dans la partie inférieure du remplissage, la formation SDLF est caractérisée par des sédiments dolomitiques surmontés d'une épaisse couche constituée de séquences de lamines carbonatées. Ces dépôts se seraient formés par précipitation chimique en milieu lacustre peu profond et confiné (milieu endoréique). Cette formation n'a été repérée que dans la partie centrale du marais, correspondant aux zones de bassins les plus profondes de l'ancien lac (faciès distaux). Les dépôts plus superficiels (formation CF) sont principalement de nature détritique argilo-silteuse et sont riches en calcite. Ils traduisent un milieu exoréique. Ils se retrouvent dans presque toute l'ancienne zone lacustre, aussi bien en position distale que proximale (deltas et bassins). Afin de connaître la géométrie des dépôts dans le marais et de distinguer SDLF de CF dans les zones de bassin, une prospection géophysique électromagnétique a été effectuée au moyen d'un conductivimètre EM31 (méthode slingram). Seize sondages électriques ont aussi été réalisés sur différents secteurs du marais.

Les mesures électromagnétiques permettent d'établir une carte de conductivité apparente du site dans ses parties nord et sud. Nous mettons ainsi en évidence la présence d'une zone fortement conductrice dans l'axe central N-S du marais, plus prononcée au sud. Cette zone est entourée de terrains plus résistants et hétérogènes, où des poches conductrices sont repérées. Aucun paléochenal surcreusé dans le substrat n'est mis en évidence. Nous montrons qu'il n'existe pas de corrélation nette entre la conductivité apparente et l'épaisseur totale de sédiments lacustres. Par contre, l'axe central
\end{abstract}

1. UPRES EA 2100, Lab. GéEAC, Univ. François Rabelais, Parc de Grandmont, 37200 Tours, France. Florent.hinschberger@univ-tours.fr 2. UMR 7619 Sisyphe, Univ. Pierre et Marie Curie (Paris 6), case 105, 4 place Jussieu, 75252 Paris cedex 05, France. Guerin@ccr.jussieu.fr Manuscrit déposé le 19 décembre 2005 ; accepté après révision le 29 mai 2006. 
très conducteur du marais correspond aux zones distales de l'ancien lac, reconnues ponctuellement grâce aux carottages. Dans le remplissage des zones distales, la formation SDLF se signale sur les sondages électriques par une très faible résistivité (environ 1,2 $\Omega . \mathrm{m}$ ), expliquant la forte conductivité apparente des faciès distaux. Nous utilisons enfin les données géophysiques, en complément des informations fournies par les carottages, pour évaluer l'étendue et le volume de la formation SDLF sur l'ensemble du marais. Cette étude montre finalement qu'il est possible d'utiliser la géophysique pour différencier entre eux, au sein d'un remplissage sédimentaire à faciès peu différenciés (silts argileux carbonatés), des dépôts lacustres formés dans des conditions très différentes, par précipitation chimique dominante d'une part, et par sédimentation détritique dominante d'autre part.

\section{INTRODUCTION}

Lacustrine sediments are very good archives allowing us to quantify a sediment budget in a catchment and to reconstruct sediment yield and deposit paleoenvironments [Gay, 1995; Bossuet et al., 1996; Macaire et al., 1997, 2002; Einsele and Hinderer, 1998; Hinderer, 2001; Buoncristiani et al., 2002]. For the recent periods (Lateglacial and Holocene) these archives are generally analysed from core drillings, which provide precise but laterally confined information on sediment extent. The geophysics often completes advantageously the local observations deduced from the boreholes, allowing for the rapid 3D determination of the sedimentary unit distribution over wide areas [Bossuet et al., 1993, 2000; Bendjoudi et al., 2002; Buoncristiani et al., 2002; Gourry et al., 2003; Froese et al., 2005]. Applied geophysical methods successfully contribute to the quantitative evaluation of the volume of deposits stored in lacustrine depressions, so as to estimate the sediment yield from the catchment at different periods and for various paleoenvironmental contexts [Bossuet et al., 1996; Dupis et al., 1996]. Among the numerous geophysical tools, electric and electromagnetic prospecting have already shown their use for the rapid and non-intrusive mapping of surficial deposits, including alluvial bodies structure determination [Bendjoudi et al., 2002; Gourry et al., 2003; Froese et al., 2005]. In favourable cases, these methods allow the discrimination of the lacustrine sediments from the substrate, as well as the imaging of bedrock topography [Bossuet et al., 1993, 2000]. They also enable us to distinguish, within the infilling, the coarse sediments generally deposited in basin border or deltaic environments, from the finer sediments, often related to the more distal parts of lacustrine basins [Dupis et al., 1996]. Finally, silty-clayey and/or peaty paleochannels can be also easily detected [Gourry et al., 2003]. However, the different fine lacustrine lithologic units, such as lacustrine chalk and silty / clayey sediments, are often more difficult to discriminate from geophysical data [Bossuet et al., 1993, 2000].

The Sarliève marsh (Massif Central, France) is an ancient lake (about $5 \mathrm{~km}^{2}$ ), which has been dried up by humans since the XVII ${ }^{\text {th }}$ century [Fournier, 1996]. It is located in a small closed catchment of $29 \mathrm{~km}^{2}$, and is filled with Lateglacial to historic sediments [Gachon, 1963; Fourmont, 2005]. In order to quantify the anthropic impact on sediment yield and lacustrine sedimentation, the Sarliève marsh was the focus of a detailed sedimentological analysis supplemented by archeological prospecting [Fourmont, 2005]. Drillings have shown the presence of two main types of fine grained lacustrine sedimentary formations lying on a more compact marly substratum. These two formations differ in their origin, detailed lithology and geographic extension but they are both mainly made of clayey silt [Fourmont, 2005]. The lower one (silicated and dolomitic laminated formation or "SDLF") results mainly from chemical precipitation in an endoreic environment, with a rather low anthropic impact. It seems to be located only in the depocenter (or distal areas) of the marsh, both in its northern and southern parts. The upper one (calcitic formation or "CF") is found in the whole lacustrine area and has a detrital origin (exoreic environment). The impact of human activities on mechanical erosion processes strongly increased during the CF deposition. These two types of fine sedimentary formations are difficult to clearly distinguish from the core data, which allow only uncertain extrapolations of their geographical extent. This is especially the case of the SDLF, which is found at 2 to $3 \mathrm{~m}$ depth, and the extent of which is more difficult to study. However, they must be precisely identified within the whole marsh before quantifying the anthropic impact on the lacustrine sedimentation. For this aim, we used two complementary geophysical techniques, the slingram electromagnetic method [McNeill, 1980a; Frischknecht et al., 1991] and electrical sounding (ES). The main objective of our study was to test whether the geophysical survey was able to distinguish, among the whole fine lacustrine deposits, the endoreic SDLF from the exoreic CF, and then to precise the geometry of the lacustrine filling.

\section{GEOLOGICAL SETTING AND LACUSTRINE FILLING}

The Sarliève marsh (altitude $344 \mathrm{~m}$ ) is located near Clermont-Ferrand, on the foothill of the oppidum of Gergovie (749 m) (fig. 1). The ancient lake is located in the Oligocene Limagne rift, which crosses the French Massif Central along a north-south direction. The lake catchment is mainly made of marly to calcareous Upper Oligocene sediments, and of surficial deposits (mainly colluviums) [Jeambrun et al., 1973]. Some basaltic formations outcrop on the hill tops (Plateau de Gergovie, Puy d'Anzelle and Puy de Bane). River deposits inherited from the Allier River also occur as terraces bordering the ancient lake [Jeambrun et al., 1973; Lenselink et al., 1990]. According to Derruau [1949], the formation of the Sarliève marsh results from a dam due to a "Magdalenian" alluvial fan, the so-called Cône de l'Artière, in the northern part of the watershed. However others, such as Gachon [1963], consider that the lake is located in a depression dug into the substratum during the Pleniglacial (between 40,000 and 20,000 years BP). Trément et al. [2005] showed that the outlet is dammed by mud flow deposits, probably emplaced during the Older Dryas on a shelf bordering the depression. Today, the Sarliève marsh is totally drained and cultivated. However, some parts of the marsh remain temporarily flooded. A 


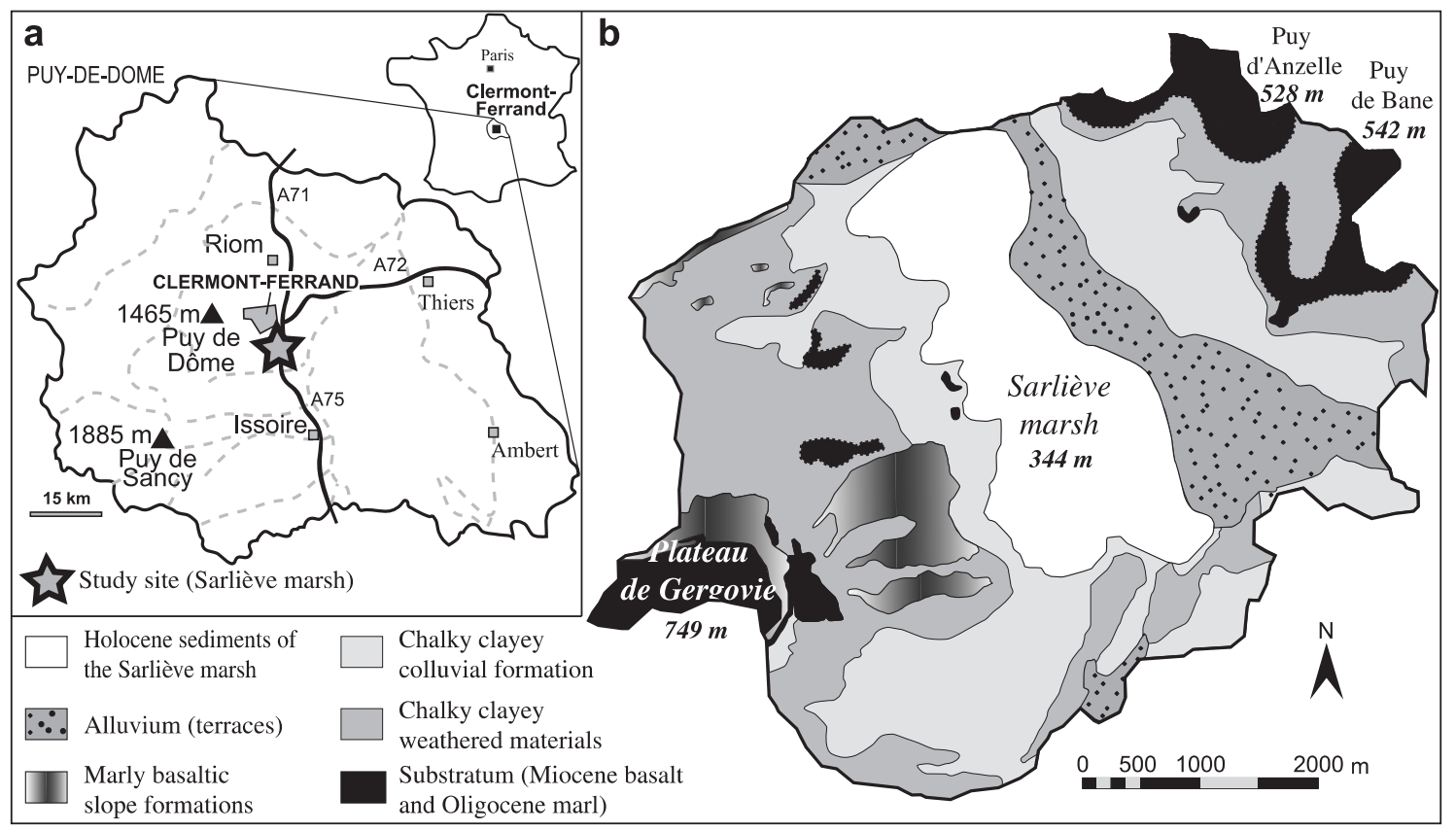

FIG. 1. - Location and geology of the Sarliève marsh. a. Study site location. b. Simplified geology of the Sarliève marsh catchment. FIG. 1. - Localisation et géologie du bassin de Sarliève. a. Localisation du site étudié. b. Géologie simplifiée du bassin versant du marais de Sarliève.

drainage pipe (namely "Grande rase") crosses the entire marsh in a N-S direction. The direction of drainage is from south to north.

30 cores and 13 excavations were analysed. They have shown the presence of three main types of sedimentary filling in the Sarliève marsh (fig. 2). The first type ("Type A" of Fourmont [2005]) corresponds to the distal lacustrine sedimentary (DLS) filling, which covers the widest zone in the marsh. It is found in the depocenter of two sub-basins, both in the northern and southern parts of the ancient lake. As it can be seen on figure $2 b$, this type is characterized by 5 to $6 \mathrm{~m}$ of clayey silty carbonated sediments. Above the Oligocene bedrock, it is composed, from the base to the top, of (i) the silicated and dolomitic laminated formation (SDLF), showing (i1) a thin clayey-silty compact silicate-rich unit, (i2) a blue grey clayey authigenic dolomite-rich unit [Bréhéret et al., 2003], and (i3) a thick stacking of decimetric sequences composed of a system of dolomitic and aragonitic pile of chalky laminae interbedded with grey to brown greenish clayey silty sediments, and (ii) the calcitic formation $(\mathrm{CF})$, corresponding to homogeneous green to pale grey carbonated (calcite) clayey silty sediments, including a dark grey to black layer ("Couche noire") several decimetres below the topsoil. The second type ("Type B" of Fourmont [2005]) corresponds to the proximal lacustrine sedimentary filling, which is found at the periphery of the northern and southern basins. It is composed, from the base to the top, of (i) a pluridecimetric black sandy layer, partly inherited from the redistribution of a tephra (CF1 from Vernet and Raynal [2000]), and (ii) the CF. The SDLF is lacking in the proximal lacustrine zone. The third type ("Type D" of Fourmont [2005]) corresponds to metric to plurimetric deltaic sandy deposits, partly composed of in situ CF1, and CF1 and alluvial terrace reworked deposits. It is located in the narrow medium part of the marsh, between the northern and southern sub-basins.
Finally, the borders of the marsh present few or no lacustrine sediments, but colluvium and/or mudflow deposits ("Type C" of Fourmont [2005]).

\section{GEOPHYSICAL METHODS AND DATA ACQUISITION}

The geophysical surveys were performed in summer, when the terrain is driest. However, an electromagnetic test profile across the marsh was also performed in January, in order to check if the observed conductivity variations are strongly influenced by temporary hydrological factors (fig. 3).

\section{Electromagnetic survey}

The slingram electromagnetic survey was performed using an instrument called "EM31" (Geonics Ltd.). The principle of operation is precisely described by McNeill [1980a] and Guérin et al. [2002]. The instrument indicates the apparent electrical conductivity of the ground [McNeill, 1980b]. The measured conductivity, or its converse, the apparent electrical resistivity, closely depends on the lithology of the surficial deposits. In the case of a resistive substratum, low conductivities are usually associated with the presence of coarse deposits (sand and/or gravel) or thin sedimentary filling, whereas high conductivities may indicate a thick layer of fine deposits (clays and/or silts) [McNeill, 1980a]. We used the instrument in "vertical dipole" array, where the depth of investigation is approximately $6 \mathrm{~m}$ deep. It means that the measured apparent conductivity is strongly sensitive to changes in the upper layers up to $6 \mathrm{~m}$ deep, making this instrument appropriate for the study of the Sarliève marsh sedimentary filling, the thickness of which ranges from between 0 to $6 \mathrm{~m}$ as indicated by the borehole data. The contribution of the 50 first centimetres of the ground is 


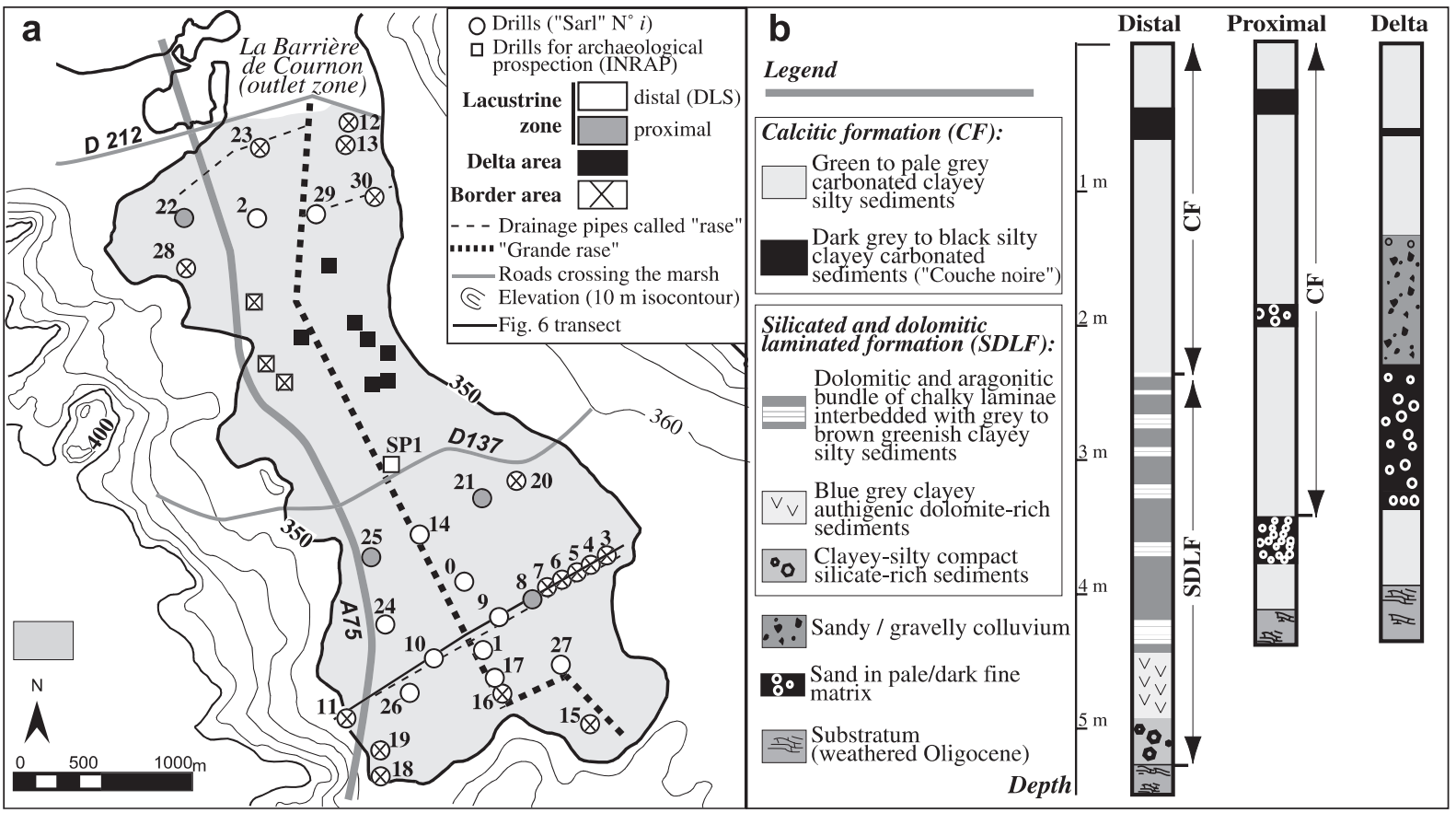

FIG. 2. - Sedimentary filling of the Sarliève marsh. a. Location of drills and corresponding sedimentary filling types (distal and proximal lacustrine zones, delta, and border areas). b. Typical stratigraphy of distal, proximal and deltaic sedimentary filling.

FIG. 2. - Remplissage sédimentaire du marais de Sarliève. a. Localisation des forages et sondages et remplissages sédimentaires correspondants (zones lacustres distale et proximale, delta, et zone de bordure). b. Colonnes stratigraphiques typiques des remplissages sédimentaires distal, proximal et deltaïque.

minor (it does not exceed $15 \%$ of the response). Then, the EM31 is not very sensitive to the near-surface deposits and structures (soil, tracks...). The measurement accuracy in conductivity is no more than $5 \%$, which is high enough considering the large conductivity range in the Sarliève marsh (about $500 \%$ ). The spatial resolution is about $5 \mathrm{~m}$. Finally, the EM31 does not require electrical contact with the ground, allowing us to go through the flooded zones of the marsh as well as in the cultivated areas.

We performed about $50 \mathrm{~km}$ of electromagnetic profiles within the Sarliève marsh, representing 7,000 measurement points. These profiles are shown as black or white dotted lines in figure 4. The EM31 data were collected continuously along the profiles, with an average measurements interval of $7 \mathrm{~m}$. The spacing between the profiles is much larger, ranging from 20 to $100 \mathrm{~m}$. The majority of profiles are oriented in an ENE-WSW direction, perpendicular to the axis of the depression, so as to highlight possible transverse ruptures in the marsh sedimentary filling. However, owing to the great number of profiles, longitudinal transitions will also be imaged, but with a lower accuracy. The data were then interpolated by kriging using a $20 * 20 \mathrm{~m}$ grid with Arcmap software. The resultant conductivity map is shown in figure 4 . We did not consider the measurement points located $20 \mathrm{~m}$ apart the "Grande rase". Indeed, we can observe on the profiles that conductivity is heavily influenced by this channel, near which the resistivity abruptly increases. A possible explanation is that the water table level is lower near it, as an effect of ground-water discharge. The surficial deposits are then dryer, explaining their lower conductivity. However, other causes may also explain the increasing resistivity near the "Grande rase", such as changes in water table conductivity, or the presence of more resistive filling material. Finally, no profile was performed in the central part of the marsh, where the terrain has been reworked since the construction of a building in 2000 (the "Grande Halle" constructed area in fig. 4). Nevertheless, this area is well known from soil engineering prospecting.

\section{Electrical soundings (ES) survey}

In order to better define the vertical distribution of sediments and to help the interpretation of the slingram electromagnetic mapping, an ES survey was performed at 16 points within the Saliève marsh (location fig. 4). We used a Syscal Jr. resistivity meter (Iris Instrument). Some ES were made close to the boreholes, allowing for the calibration of the resistivity models. We used Wenner arrays with $\mathrm{a}=0.1$ to $40 \mathrm{~m}$ spacing between the electrodes, corresponding roughly to a depth of investigation reaching no more than $15-20 \mathrm{~m}$ in the highly conductive zones of the marsh.

\section{GEOPHYSICAL RESULTS}

\section{Conductivity map (fig. 4)}

The electromagnetic profiling survey enables the construction of a large-scale map of shallow sub-surface apparent conductivity covering about 250 ha. The map is divided into a northern and a southern part separated by the "Grande Halle" constructed area, where no geophysical data is available. The measured conductivity ranges from $48 \mathrm{mS} / \mathrm{m}(22 \Omega . \mathrm{m})$ in the $\mathrm{SW}$ and NE borders of the marsh (appearing in white in fig. 4) to $245 \mathrm{mS} / \mathrm{m}(4 \Omega . \mathrm{m})$ in its southern central part (black areas). 


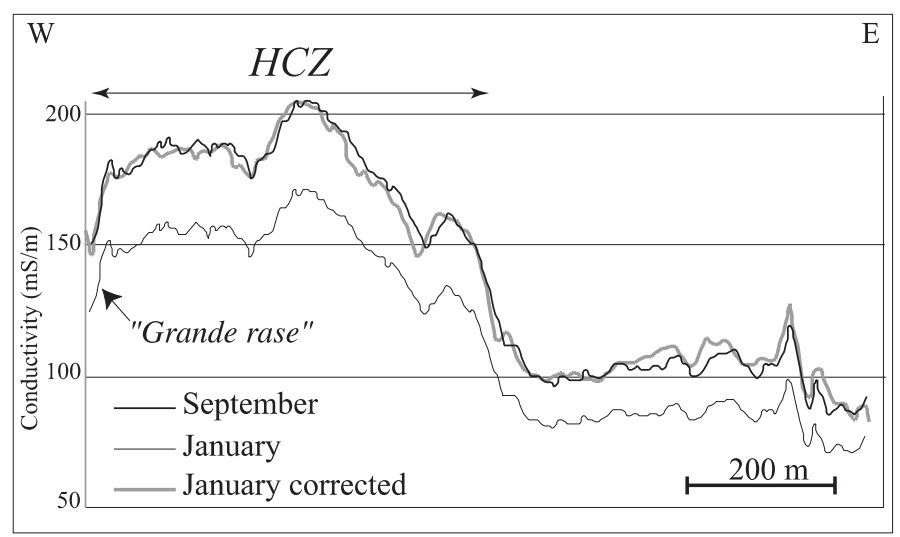

FIG. 3. - EM31 profile across the marsh (location in fig. 4) performed at two distinct periods (September and January). The January profile corrected from temperature influence is also indicated. It was established using the Keller and Frischknecht [1966] function with an average temperature difference of $7^{\circ} \mathrm{C}$ from 0 to $6 \mathrm{~m}$ depth. HCZ: highly conductive zone. FIG. 3. - Profil EM31 à travers le marais de Sarliève (localisation fig. 4) réalisé à deux époques différentes (septembre et janvier). Le profil de janvier corrigé de l'influence de la température est aussi indiqué. Il a été établi en utilisant la relation de Keller et Frischknecht [1966] avec une différence de température entre l'été et l'hiver égale à $7^{\circ} \mathrm{C}$ en moyenne entre 0 et $6 \mathrm{~m}$ de profondeur. $\mathrm{HCZ}$ : zone fortement conductrice.

The EM31 survey highlights a large conductive feature running parallel to the axis of the depression in the south central part of the Sarliève marsh. This highly conductive zone (dark grey to black "HCZ" zone in fig. 4) is characterized by conductivity values ranging from about 130 to $245 \mathrm{mS} / \mathrm{m}$, and is more pronounced east of the "Grande rase". It has an abrupt linear boundary on its eastern side, where the measured apparent conductivity increases from about $100 \mathrm{mS} / \mathrm{m}$ to more than $150 \mathrm{mS} / \mathrm{m}$ over a distance of $50 \mathrm{~m}$. No structure, topographic discontinuity or modification in the landscape is visible in this area. This boundary can be followed for $1.2 \mathrm{~km}$. In the southern termination of the marsh however, the transition is irregular and less marked, especially to the SW where it is very progressive. The western boundary of the HCZ is abrupt, but sinuous, showing a large resistive promontory. Finally, the HCZ reaches a maximum width of $1,200 \mathrm{~m}$, and narrows towards the north. Unfortunately, the lack of geophysical data in the "Grande Halle" constructed area does not provide any conclusive evidence as to whether it continues or ends through the central part of the marsh. Surrounding the $\mathrm{HCZ}$, the marsh field shows intermediate conductivity of about $100 \mathrm{mS} / \mathrm{m}$, which appears in white in figure 4 . To the east however, conductive structures are imaged at some places, but they present no clear organisation and do not seem to be connected. More resistive values (about $60 \mathrm{mS} / \mathrm{m}$ ) are recorded in the west (white zone in fig. 4), but this area corresponds to the Oligocene substratum and so lies outside the marsh.

The northern part of the Sarliève marsh globally shows lower conductivity than the southern one. Nevertheless, a more conductive zone is also imaged in the middle of the marsh, but its conductivity does not exceed $140 \mathrm{mS} / \mathrm{m}$. It is surrounded by more resistive terrains, especially to the NE where we record $48 \mathrm{mS} / \mathrm{m}$, and seems to stop towards the south. Finally, as in the southern part of the marsh, conductive structures are highlighted in the east, but they are disconnected from the central conductive zone.
In conclusion, the Sarliève marsh is characterized by a large central conductive zone, more pronounced in its southern part, surrounded by more resistive but heterogeneous bordering terrains.

\section{ES data}

On the basis of their curve's shape, the ES can be divided into two clearly distinct groups (fig. 5a). Four electrical soundings (ES 1, 2, 4 and 5) show a drop of the apparent resistivity for a $>2 \mathrm{~m}$, suggesting the presence of a very conductive layer at low depth (about 2-3 m deep). It is worthnoting that these ES are located within the HCZ. All the other ES (except ES 18) lie in the more resistive bordering terrains. They globally present little resistivity contrasts, apart from a slight decrease for a $>5$ to $7 \mathrm{~m}$. Finally, the ES 18 is located SW of the marsh, in the area of progressive transition between the $\mathrm{HCZ}$ and the bordering terrains. It shows intermediate characteristics of the two groups of ES.

\section{INTERPRETATION AND DISCUSSION}

As the investigated area within the Sarliève marsh is very flat, the depth of the water table level may not vary significantly and abruptly, except near the drainage pipes where the geophysical data were filtered. In the other areas, the water table level is found at about zero to a few decimetres below the ground. Moreover, the EM31 test profile realized in winter across the marsh is very similar to the one performed at the same place in summer (fig. 3). Thus, the abrupt conductivity variations observed in figure 4 may be principally interpreted in terms of geological changes. However, the influence of possible permanent space variations of the water table conductivity cannot be ruled out. In the same way, the cores show no major heterogeneities in the substratum, which is constituted of clayey-silty marly sediments. Nevertheless, local enrichments in sand appear at some places.

\section{Conductivity vs. sediment thickness}

We first looked for possible correlation between the measured conductivity and the marsh sediment thickness, which is locally known from the boreholes. Figure 6 is a schematic geological transect across the southern part of the marsh elaborated from 10 boreholes. The corresponding EM31 profile is superimposed to it. East of the "Grande rase", we can observe a clear correlation between the two parameters: the thicker the sediment, the higher the conductivity $\left(\mathrm{R}^{2}=0.77\right.$ in the figure 7 a diagram). To the east, where the substratum is found at about $1 \mathrm{~m}$ below the ground (thin border sediments of Sarl 3 to Sarl 7 cores), the average conductivity is around $100 \mathrm{mS} / \mathrm{m}$, but the profile shows strong variations, with high conductivity at some places. This globally resistive area corresponds to the white to light grey bordering terrain seen on the conductivity map (fig. 4), where conductive structures are imaged. Since the EM31 is more sensitive to the terrain below $1 \mathrm{~m}$ depth, we suggest that the observed conductivity variations are principally due to the presence of heterogeneities in the unevenly weathered substratum, locally covered with colluvium. Such heterogeneities are locally observed from the boreholes. They may also affect the substratum below the HCZ, but here their geophysical signature is masked by the great thickness of sediment. Indeed, the 
EM31 is less sensitive to the terrains below $6 \mathrm{~m}$ depth. At about $\mathrm{X}=1,500 \mathrm{~m}$ on the transect (fig. 6), just east of the Sarl 8 core, the conductivity abruptly increases from 100 to $130 \mathrm{mS} / \mathrm{m}$. We can observe on the geological transect that this zone corresponds to the eastern boundary of the proximal lacustrine sediments, where the sediment thickness increases from about $0.5 \mathrm{~m}$ in Sarl 7 core to $4.20 \mathrm{~m}$ thick in
Sarl 8 core. After a stabilization, we note a second increase of the apparent conductivity from 150 to $175 \mathrm{mS} / \mathrm{m}$ at $\mathrm{X}=1,350 \mathrm{~m}$, between Sarl 8 and Sarl 9 cores. Then the conductivity remains high and regular, except a slight "resistive" anomaly at $X=1,125 \mathrm{~m}$ (fig. 6). Near the "Grande rase", conductivity abruptly decreases, probably as an effect of ground-water discharge. However, west of the drainage

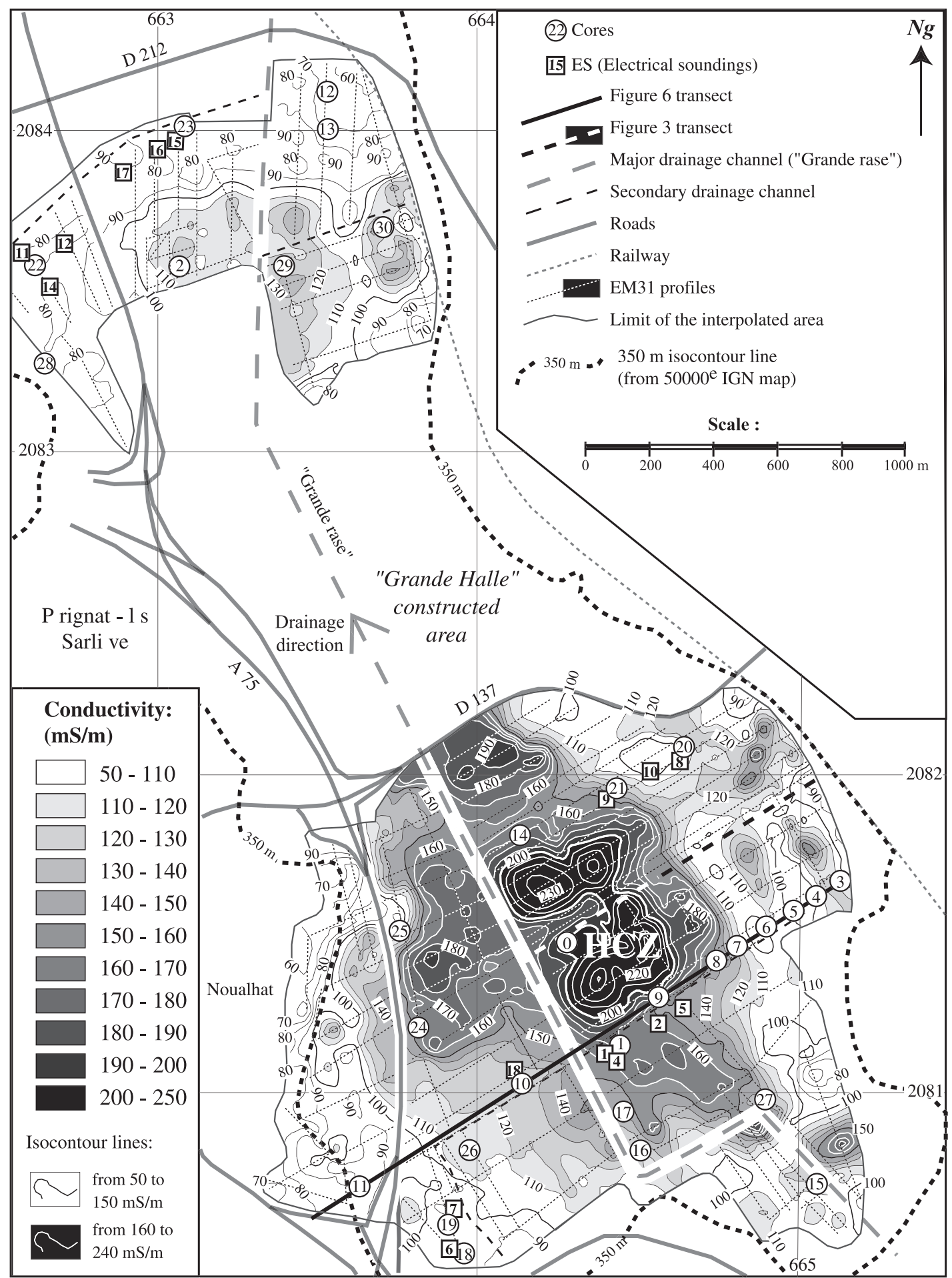

FIG. 4. - Conductivity map (EM31) of the Sarliève marsh. Isocontour lines are reported every $10 \mathrm{mS} / \mathrm{m}$. EM31 profiles are indicated with black or white dotted lines. The boreholes, electrical soundings and figures 3 and 6 transects are localized.

FIG. 4. - Carte de conductivité (EM31) du marais de Sarliève. Les lignes isocontour sont reportées tous les 10 mS/m. Les profils EM31 sont indiqués par des traits noir ou blanc en pointillés. Les carottages, sondages électriques et transects des figures 3 et 6 sont aussi localisés. 


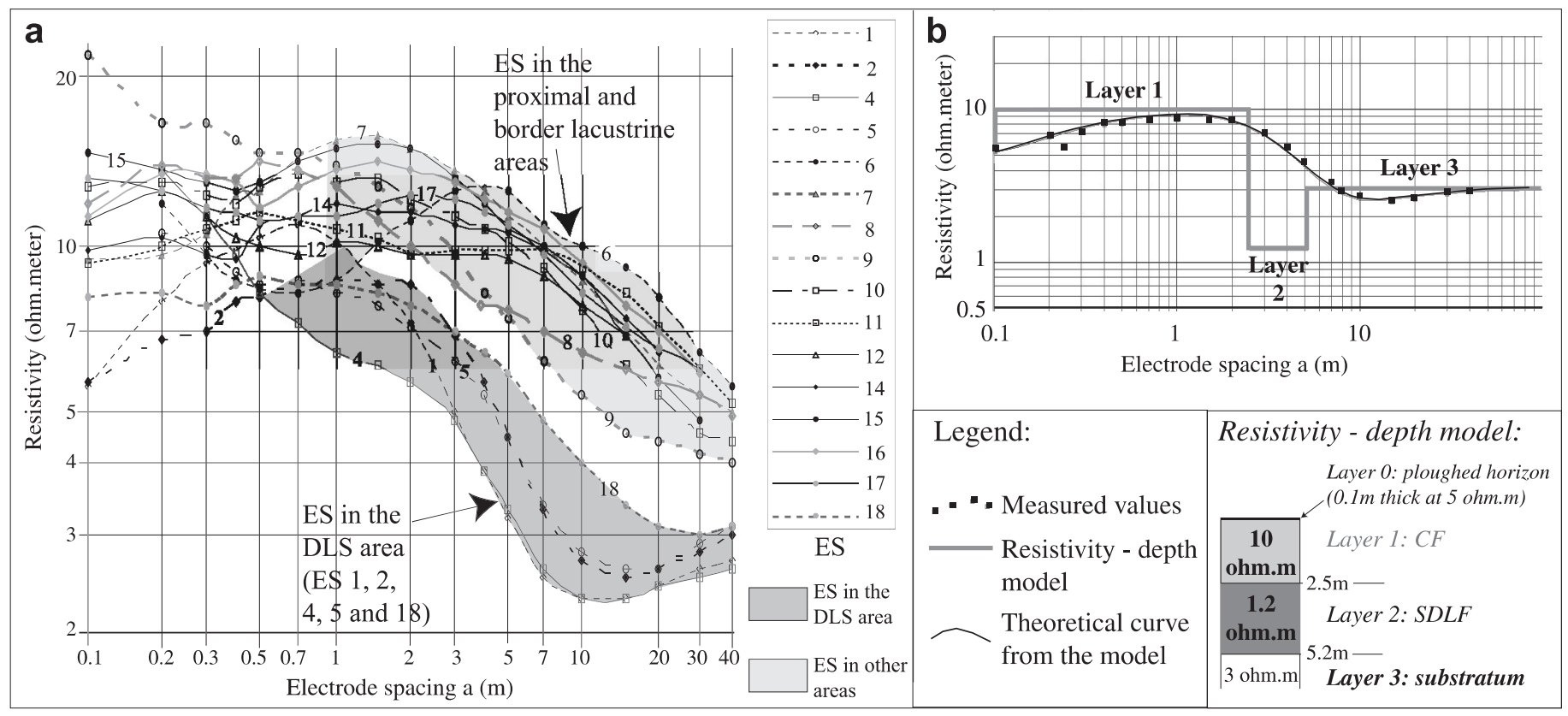

FIG. 5. - Electrical soundings (ES) performed within the marsh (Wenner array). a. All ES (measured values). b. ES 2 resistivity model. CF: calcitic formation; SDLF: silicated and dolomitic laminated formation.

FIG. 5. - Sondages électriques (ES) réalisés dans le marais de Sarliève (montage Wenner). a. graphique de tous les sondages. b. Modèle de résistivité pour le sondage $n^{\circ}$. CF : formation calcitique; SDLF : formation siliceuse et dolomitique laminée.

channel, conductivity does not reach the high values measured more to the east: it ranges from 120 to $150 \mathrm{mS} / \mathrm{m}$, although 5 to $6 \mathrm{~m}$ thick of lacustrine sediments are observed in the Sarl 10 and Sarl 26 cores. This may indicate that the "Grande rase" constitutes a boundary separating two different water levels of distinct conductivity. Nevertheless, a little more northward, conductivity west of the "Grande rase" remains high and the effect of the drainage pipe is less pronounced (fig. 4). Finally, on the western termination of the transect, conductivity progressively decreases below $100 \mathrm{mS} / \mathrm{m}$. This area corresponds to the bottom of the depression side, where thin border sediments are found (Sarl 11 core). The correlation coefficient between measured conductivity and marsh sediment thickness for the western part of the transect is high $\left(\mathrm{R}^{2}=0.92\right.$ in fig. $\left.7 \mathrm{a}\right)$, but it results from 3 cores only, making it quite insignificant.

The figure $7 \mathrm{~b}$ shows that the correlation between measured conductivity and sediment thickness cannot be extended to the whole marsh area, even if we consider separately its southern and northern parts $\left(R^{2}=0.54\right.$ and 0.27 , respectively). Indeed, a few cores present important sediment thicknesses, whereas the corresponding measured conductivity is low. This is especially the case of the Sarl 22 core in the northern part of the marsh, where we record $4.55 \mathrm{~m}$ thickness of sediment and a conductivity of $80 \mathrm{mS} / \mathrm{m}$, and Sarl 25 in its southern part (4.75 m thickness of sediment and a conductivity of $100 \mathrm{mS} / \mathrm{m})$. However, these two cores are characterized by the presence of sandy layers (proximal sedimentary filling), that can explain the lower conductivity measured at these points. More generally, if we do not consider the 4 cores (Sarl 8, 21, 22 and 25) where proximal lacustrine sediments were found (fig. 2), the correlation becomes better $\left(\mathrm{R}^{2}=0.66\right.$ to the south and 0.61 to the north; fig. $7 \mathrm{c}$ ). Thus, it appears that we must also take into account the sedimentary filling type before interpreting the geophysical data.

\section{The distal lacustrine sediments (DLS)}

On the transect of figure 6, we can observe that the increase of the apparent conductivity from 150 to $175 \mathrm{mS} / \mathrm{m}$ at $\mathrm{X}=1,350 \mathrm{~m}$ seems to correspond to the DLS boundary. Indeed, the Sarl 8 core presents a thick $(4.2 \mathrm{~m})$ proximal sedimentary filling, whereas the Sarl 9 core located more westwards shows a thick $(5.2 \mathrm{~m})$ DLS filling. More generally, all the cores located within the HCZ present the DLS facies (Sarl 0, 1, 9, 14, 17, 24 and 27 cores; figs. 2 and 4). Alternatively, all the cores showing the DLS facies in the southern part of the marsh are located in the HCZ, except the Sarl 10 and Sarl 26 cores. These two boreholes are located SW of the marsh, in the progressive transition zone between the $\mathrm{HCZ}$ and the more resistive bordering terrains.

The 4 ES located within the HCZ allow us to precise the depth of the conductive layer responsible for the high conductive zone. Indeed, we inversed these ES by taking into account the thicknesses of the different sedimentary units recognized on the Sarl 1 and Sarl 9 neighbouring cores. Figure $5 \mathrm{~b}$ presents the model obtained for the ES 2, based on Das and Verma's [1980] inversion method. It shows a highly conductive layer $(1.2 \Omega . \mathrm{m}$, or $833 \mathrm{mS} / \mathrm{m})$ at $2.5 \mathrm{~m}$ depth and corresponding to the SDLF (if we do not consider the thin silicated layer at the base), whereas the CF is more resistive (10 $\Omega . \mathrm{m}$, or $100 \mathrm{mS} / \mathrm{m})$. Alternatively, the ES 18 curve (fig. 5a) accords well with a thinner SDLF (silicated layer excepted) conductive layer at this place, as is observed on the Sarl 10 core located close to it. It then appears that the thicker the SDLF is, the higher the conductivity. Finally, this correlation well applies for the whole southern part of the marsh, as can be seen on figure $7 d\left(R^{2}=0.88\right.$ if we exclude 


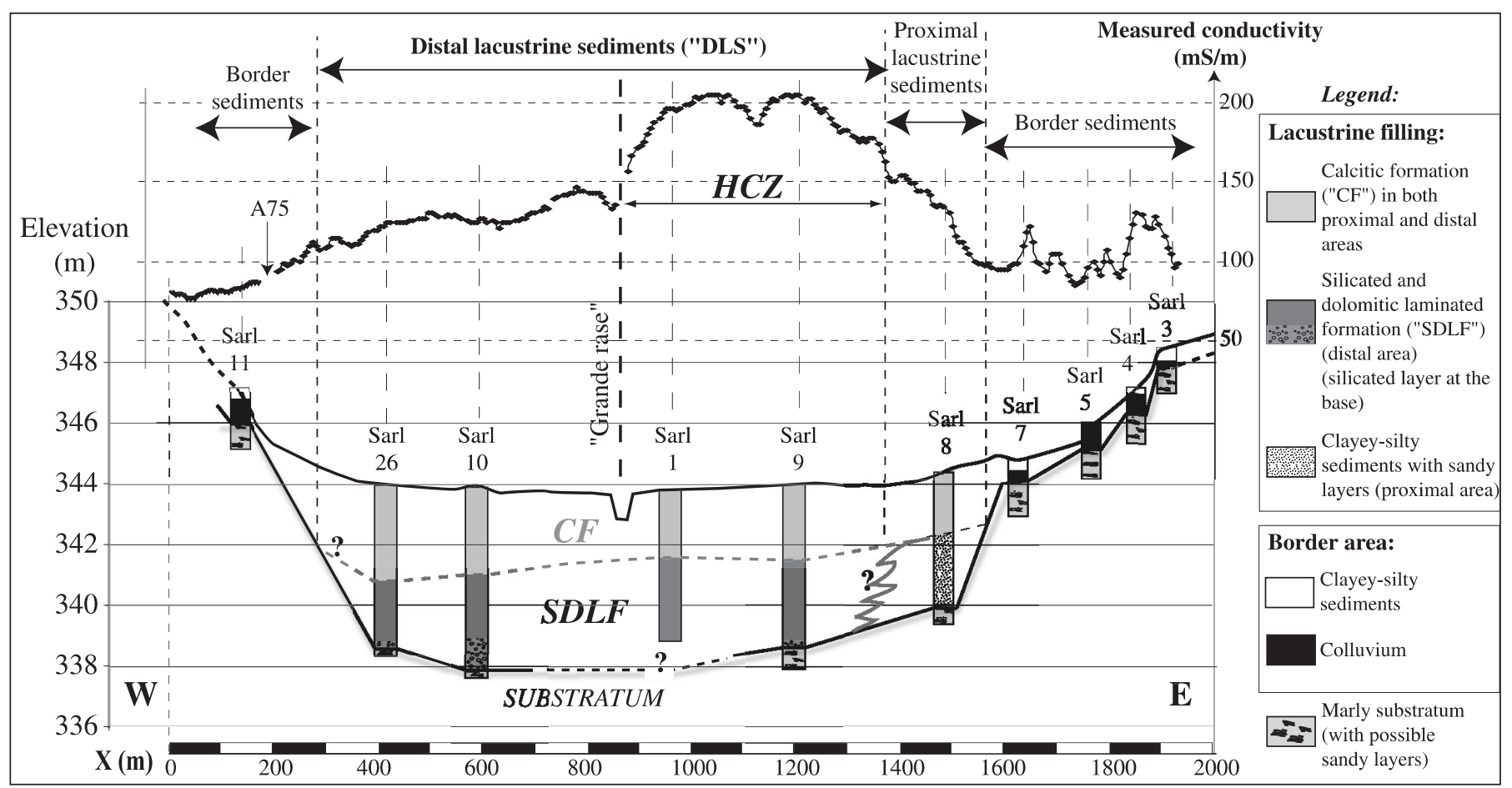

FIG. 6. - EM31 profile across the Sarliève marsh (location figs. 2 and 4). The geological transect elaborated from 10 boreholes is also shown, and the corresponding sedimentary filling types are precised.

FIG. 6. - Profil EM31 à travers le marais de Sarliève (localisation figs. 2 et 4). La coupe correspondante, établie à partir de 10 carottages, est aussi reportée. Les types de remplissage sédimentaire sont précisés.

the Sarl 14 core). The Sarl 14 core site is less conductive than expected considering the great thickness of SDLF measured at this place ( $3 \mathrm{~m}$ thick). However, we note the presence of an E-W more resistive axis in this area (fig. 4), which may be due to the presence of a resistive body within the substratum or in the more surficial deposits (ancient drainage axis).

Thus, the HCZ in the southern part of the marsh appears to correspond to the distal - or depocenter - lacustrine sediment area, and more precisely to the SDLF. The high conductivity of the SDLF can be explained by its chemistry and structure. Bréhéret et al. [2003] showed that the dolomite is authigenic: it formed as the result of sulfato-reducer bacteria activity in brackish to salty restricted waters (endoreic and low-depth basin) presenting high $\mathrm{Mg} / \mathrm{Ca}$ ratio and $\mathrm{SO}_{4}{ }^{2-}$ concentration. Now, the water table is trapped by the impermeable marly substratum and therefore it stagnates in the middle of the basin. We then suggest that, being in contact with the chalky and dolomitic sediments, the water may become highly mineralised with $\mathrm{Ca}^{2+}, \mathrm{Mg}^{2+}$ and $\mathrm{SO}_{4}^{2-}$ ions, which present high ionic conductivity. Moreover, the average measured volumetric mass of the dolomite $\left(1.0 \mathrm{~g} . \mathrm{cm}^{-3}\right)$ and chalky laminites $\left(0.75 \mathrm{~g} \cdot \mathrm{cm}^{-3}\right)$ is lower than the one of the CF sediments (1.75 to $\left.2.0 \mathrm{~g} . \mathrm{cm}^{-3}\right)$ [Fourmont, 2005]. This can be due to a higher content in organic matter, or to the fabric of sediments inducing a higher porosity of the SDLF. We suggest that all these factors - highly mineralised water combined to high porosity, high organic matter content make the SDLF a very conductive layer.

In the northern part of the marsh, the central conductive zone is less pronounced but we propose that it also marks the extent of the DLS. Indeed, the Sarl 2 and Sarl 29 cores located within the conductive zone present the DLS filling, which is absent in all the other cores lying in the more resistive bordering terrains (Sarl 12, 13, 22, 23, 28 and 30 cores). A possible explanation for the lower conductivity of the northern conductive zone compared to the southern one could be a change in CF lithology (more sandy) and/or the presence of a more resistive water table in the north. We prefer this latter hypothesis. Indeed, the outlet of the Sarliève marsh is located in the NE corner of the studied area, and may allow the groundwater to drain away from the marsh and then to stagnate for a shorter period of time.

Finally, no buried paleochannel is identified from the conductivity map in the HCZ area. Such structures may be characterized by coarser deposits, and may then appear as a resistive corridor running globally NNW-SSE, parallel to the elongated axis of the marsh. On the contrary, the bottom of the DLS zone appears as a relatively flat depression, except the E-W anomaly observed in the area of Sarl 14 core.

\section{The border and proximal lacustrine sediments}

All the cores located within the more resistive bordering terrains, both in the southern and northern parts of the marsh (light grey to white zones in fig. 4), present either low sediment thicknesses $(1.6 \mathrm{~m})$, or thick but sandy sediments. The first group corresponds to the border areas, that cover a wide zone in the marsh (Sarl 3, 4, 5, 6, 7, 11, 12, 13, $15,16,18,19,20,23,28$ and 30 cores). The second group corresponds to the proximal lacustrine area and is represented by 4 cores only (Sarl 8, 21, 22 and 25). Since no 
clear correlation appears between measured conductivity and sediment thickness, the border and proximal lacustrine sediments cannot be clearly distinguished from the conductivity map. Nevertheless, the boundary between them may be recognized on some EM31 profiles (for example, it may correspond to the zone of conductivity increase at $\mathrm{X}=1,500 \mathrm{~m}$ on the figure 6 transect) and therefore it can be locally mapped.

In the same way, the ES do not allow for clear differentiation between the border and the proximal lacustrine sediments. Indeed, the ES 6, 7, 8, 15, 16 and 17, which were performed close to cores showing border sediments, are globally similar to the ES 9, 11, 12 and 14 performed close to cores showing proximal lacustrine sediments (figs. 4 and 5a). More precisely, these two types are characterized by ES showing little variations, suggesting that there is no marked contrast between the resistivity of the substratum and the resistivity of the silty-clayey and sandy sediments. At some places, the sediments are a little more resistive than the substratum (ES 7, 8, 9, 15, 16 and 17), while in other areas we can hardly observe any difference between the two formations (ES 11, 12, 14), or even a more resistive substratum (ES 6). This variability could be due to the heterogeneities of the substratum, as well as the presence of colluvium, or to changes in the lithology of the sediments (more or less sandy). Regardless of which assumption is correct, the resistivity contrasts are too low to allow for the elaboration of sufficiently precise and reliable geological models from these ES. Finally, the slight decrease of resistivity for a $>5$ to $7 \mathrm{~m}$, which can be observed for all the ES, may be interpreted as an effect of a more conductive layer within the substratum (for example, the presence of a conductive water table located at about $10 \mathrm{~m}$ depth).

It then appears impossible, with electric and electromagnetic data, to clearly differentiate in the whole marsh the zones of thin border sediments from those of thick proximal lacustrine sediments. Nevertheless, geophysics allows us to precise some aspects of the geology of the Sarliève marsh borders. Among them, the resistive promontory bordering the HCZ southwest of the marsh may be a sandy lobe formed as detrital inflows originated from the slope. Indeed, the Sarl 25 core which is located on this structure presents $2.30 \mathrm{~m}$ thick sandy sediments in the lower part of the filling. In the northern part of the marsh, the central conductive zone seems to be limited to the SE by a westward projection of the more resistive bordering terrains (fig. 4). This area probably corresponds to the northern limit of the sandy delta evidenced in the medium part of the marsh from the archaeological drills [Fourmont, 2005] (fig. 2). More northwards, the low measured conductivity values (about 50 to $70 \mathrm{mS} / \mathrm{m}$ in the NE corner of the map) are coherent with a rise of the substratum at this place, as observed from the Sarl 12 and 13 cores. Moreover, no outlet is imaged from the conductivity map in the north. The northern lacustrine zone then appears to correspond to a closed depression dug into the substratum, and limited to the south by a sandy delta. Finally, as in the DLS area, no paleochannel or thalweg is identified in the border and proximal basin area. The conductive structures are not connected with each other, and so cannot be interpreted as buried channels filled with conductive fine deposits.

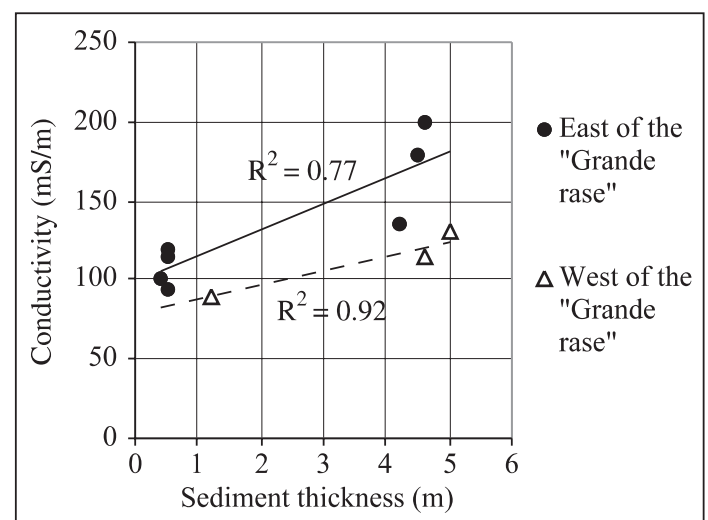

\section{$\mathbf{a}$}

Cores from the Fig. 6 transect

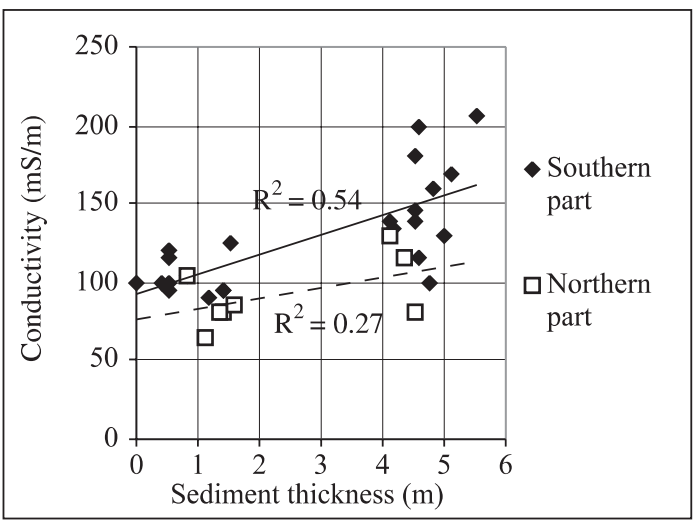

b

Whole marsh - all cores
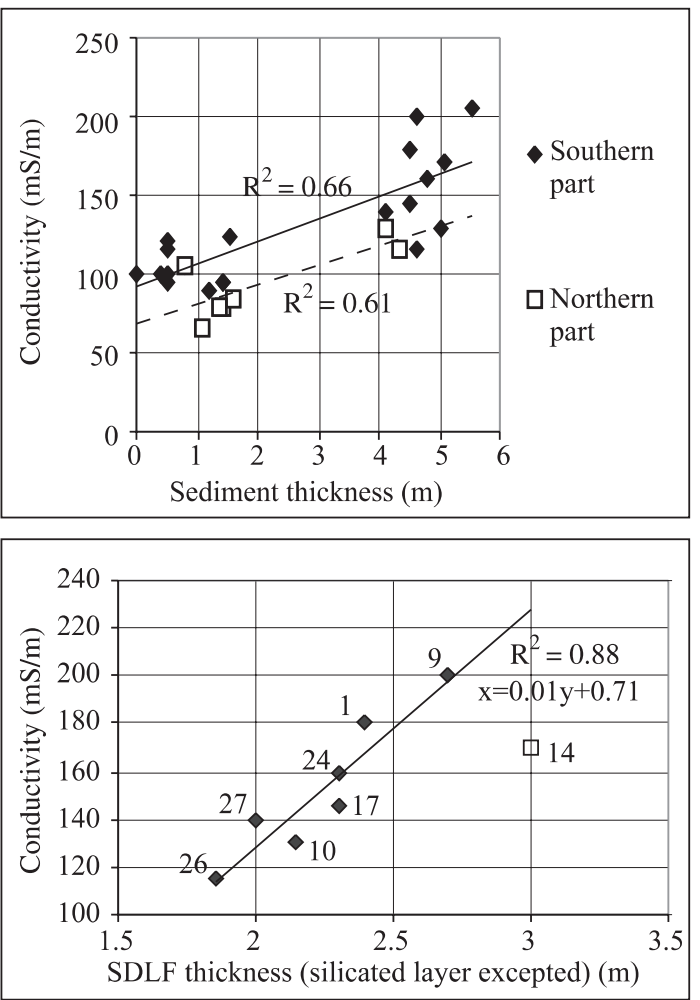

d

Cores showing the SDLF formation (southern part)

FIG. 7. - Cores data - conductivity correlations. a. Conductivity versus total sediment thickness (Cores from the figure 6 transect). b. Conductivity versus total sediment thickness (all cores). c. Same as b. without Sarl 8, 21 , 22 and 25 cores. d. Conductivity versus SDLF thickness (southern part of the marsh)

FIG. 7. - Corrélations entre les données fournies par les carottages et la conductivité. a. Conductivité en fonction de l'épaisseur totale de sédiments (carottages de la coupe de la figure 6). b. Conductivité en fonction de l'épaisseur totale de sédiments (tous les carottages). c. Idem b. sans les carottages Sarl 8, 21, 22 et 25. d. Conductivité en fonction de l'épaisseur de SDLF (pour la partie sud du marais). 


\section{Quantification of the SDLF volume from geophysical data}

We have established that the lower units of the DLS are characterized by lower resistivity than the substratum (about 1.2 and $3 \Omega . \mathrm{m}$, corresponding to 833 and $333 \mathrm{mS} / \mathrm{m}$, respectively; fig. 5b), and that the SDLF thickness is correlated to the measured conductivity (fig. 7d). This correlation can be used to calculate the theoretical extension and thickness of the SDLF, and then to quantify its approximate volume within the Sarliève marsh.

First, the theoretical lateral extent of the DLS is mapped using both the boreholes data and the conductivity map (fig. 4). In the northern part of the Sarliève marsh, we take the $110 \mathrm{mS} / \mathrm{m}$ curve as the theoretical boundary of the DLS formation. The SDLF thickness of all the points located outside this line is then set on zero. The same curve is chosen for the theoretical boundary of the DLS formation in the SW part of the marsh (west of the "Grande rase"). However, in the SE part of the marsh, we consider the $140 \mathrm{mS} / \mathrm{m}$ curve as the boundary of the DLS. Indeed, the Sarl 8 and Sarl 21 cores both lie outside the DLS zone (they present proximal lacustrine sediments), whereas we measure $135 \mathrm{mS} / \mathrm{m}$ where they are located. The difference in the geophysical response between the SE and SW parts of the

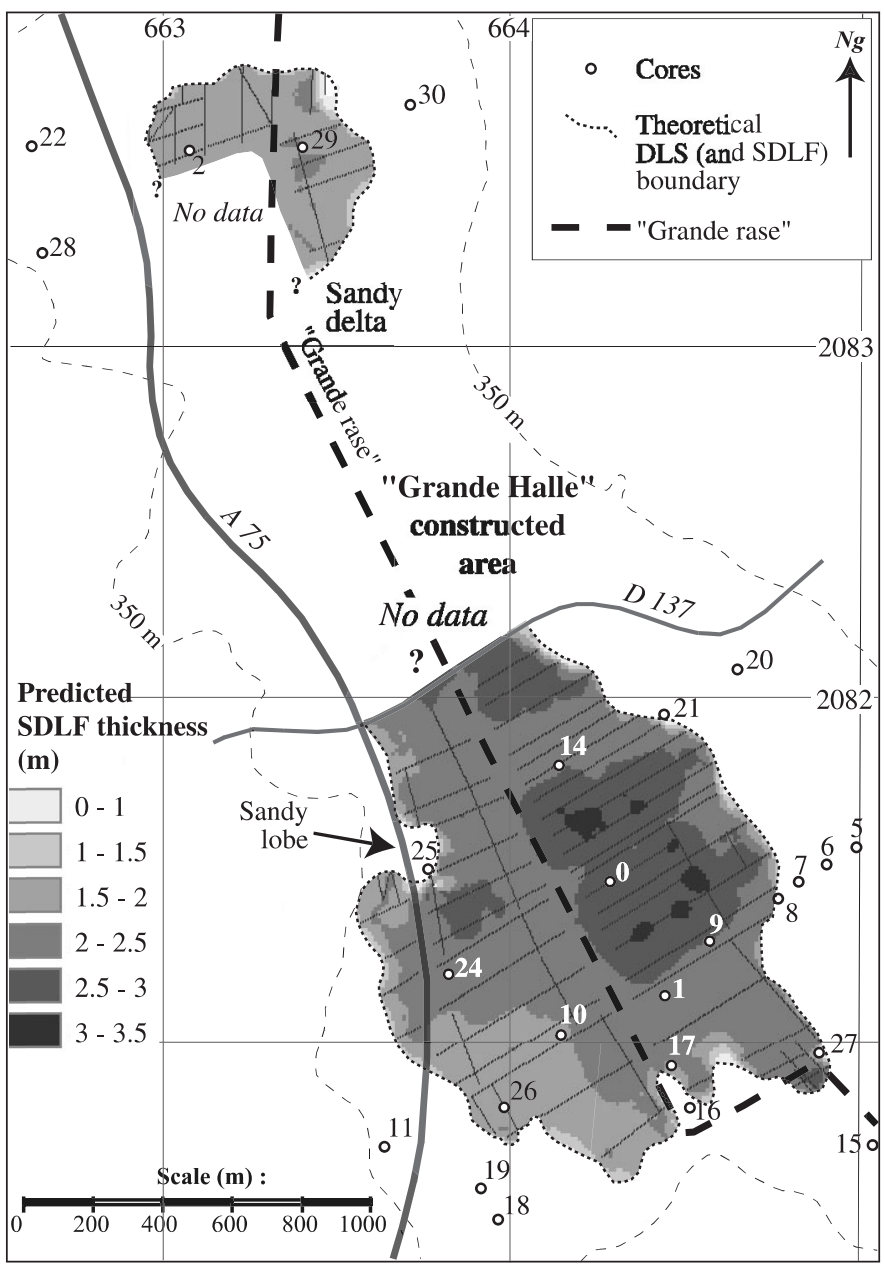

FIG. 8. - SDLF sediment thickness model of the Sarliève marsh. FIG. 8. - Modèle d'épaisseur des sédiments SDLF dans le marais de Sarliève. marsh could be due to the effect of the "Grande rase", which may constitute a boundary between two distinct water tables. We then obtain the theoretical DSL boundary imaged in figure 8 , corresponding roughly to the zones of abrupt conductivity variations observed on the figure 4 . It is of course approximate. Then, we used the SDLF thickness conductivity correlation of figure $7 \mathrm{~d}$ to calculate the theoretical SDLF thickness at each point of the $20 * 20 \mathrm{~m}$ grid inside the DLS area, both in the northern and southern parts of the marsh. The result is shown in figure 8. Logically, we can observe that the zones of maximum SDLF thickness (about $3.5 \mathrm{~m}$ ) correspond to the areas where the highest conductivity values are recorded, whereas the northern part of the marsh and its SW termination show lower SDLF thicknesses. Finally, we can calculate from this model a total volume of SDLF of about $3.7 * 10^{6} \mathrm{~m}^{3}$ covering a surface of $1.54 \mathrm{~km}^{2}$. These sediments, mainly from chemical origin, were deposited during the Boreal and Atlantic periods (9,500 to 5,000 yr. B.P.) [Fourmont, 2005]. Considering the average volumetric mass of the SDLF $\left(0.8 \mathrm{~g} . \mathrm{cm}^{-3}\right)$, we obtain a SDLF sediment yield of $43 \mathrm{t} / \mathrm{km}^{2} / \mathrm{yr}$, due to first natural erosion (Boreal period) and then to increasing human activity effects (Atlantic period). This result can be compared to the CF sediment yield calculated from the geological data, that reaches about $200 \mathrm{t} / \mathrm{km}^{2} / \mathrm{yr}$ [Fourmont, 2005]. These latter sediments are mainly detritic and were deposited during the Subboreal and Subatlantic periods, when human activity effects were predominant.

Our model is of course an oversimplification and could be improved. Indeed, many factors, which we don't take into account, may affect the measured conductivity. Among them, possible lateral changes in water table conductivity may explain the difference between the northern and southern parts of the marsh. More precisely, the presence of a relatively less conductive HCZ in the north (related to the southern one) may be partly due to a more resistive water table in this area. In this case, the SDLF thickness in the northern part of the marsh would be underestimated. In order to check whether there are significant differences in water table conductivity, some piezometers could be installed at a few points within the marsh, both in its northern and southern parts. They would allow us to take water samples at different depths from 0 to $6 \mathrm{~m}$, corresponding to the EM31 depth of investigation, and to measure their respective conductivity.

Another approximation in our estimation of SDLF thickness concerns possible variations of the substratum conductivity. Indeed, we note the presence of local resistive anomalies within the HCZ, which could be interpreted in terms of substratum structures or heterogeneities. The larger one runs E-W and crosses the southern part of the marsh in the area of the Sarl 14 borehole (fig. 4). This structure may correspond to a fault in the Oligocene marly substratum, or to the presence of an ancient drainage channel. Analog E-W faulting may explain the relatively abrupt narrowing of the HCZ in the southern part of the marsh. Alternatively, local changes in the thickness and/or lithology of the CF sediments cannot be ruled out. In the SW part of the marsh, the CF thickness reaches $3 \mathrm{~m}$, compared to about $2.5 \mathrm{~m}$ thickness in the $\mathrm{HCZ}$ area (fig. 6). On a more local scale, a slight resistive anomaly can be observed at $\mathrm{X}=1,125 \mathrm{~m}$ on the figure 6 transect and on the neighbouring EM31 profiles. This anomaly runs NNW-SSE, but it does 
not clearly appear on the conductivity map, due to the spacing of the interpolated grid $(20 * 20 \mathrm{~m})$. It may be due to an ancient drainage channel, as suggested from antiquarian maps. Nevertheless, this structure is rather narrow and its influence on our SDLF thickness model is minor.

More surprising is the general lower conductivity of the substratum in the HCZ area deduced from the ES data (fig. 5). Indeed, the conductivity of the substratum calculated from the ES located within the DLS area (ES 1, 2, 4, 5 and 18) is around $3 \Omega . \mathrm{m}$ (fig. 5), whereas all the other ES accord with a more resistive substratum. As an explanation, we suggest that the highly conductive waters trapped within the SDLF deposits may infiltrate the weathered upper layers of the marly substratum, making it more conductive.

Finally, our model does not take into account the medium part of the marsh ("Grande Halle" constructed area), where no geophysical data is available (fig. 4). However, the volume of SDLF sediments in this area may be relatively low, compared to the volume of SDLF previously calculated. Indeed, we can observe that the marsh-southern part HCZ narrows towards the north. In the same way, a resistive body (sandy delta) seems to constitute the southern limit of the marsh-northern part HCZ. Moreover, the 11 archaeological drills located in this area show no DLS deposits, except SP1 just north of the D137 road (fig. 2a). The middle-east part of the marsh may correspond to a sandy delta [Fourmont, 2005], whereas the middle-west part presents border facies sediments, without distal lacustrine deposits.

\section{CONCLUSION}

We applied geophysics tool within the Sarliève marsh with the aim to precise the distribution of the different fine sedimentary filling types locally identified from core data. It appears that the measured apparent conductivity is not directly related to sediment thickness, and that the lithology of the deposits must be also considered. The electromagnetic survey allowed for the mapping of the lateral extent of the thick distal lacustrine sediments in the two parts of the marsh. We showed that these deposits are characterized by a highly conductive layer, clearly imaged from the ES, which is located in the lower part of the filling at about $2.5 \mathrm{~m}$ deep. This layer (SDLF) corresponds to a fine grained silicated and dolomitic laminated formation deposited during the Boreal and Atlantic periods, mainly as the effect of chemical precipitation. Its thickness may not exceed $3.5 \mathrm{~m}$. The DLS cover an area of about $1.5 \mathrm{~km}^{2}$ in the investigated area, and their boundary is particularly well marked to the east, suggesting that the ancient shore lake was abrupt in this area. We finally evaluate the volume of the SDLF at about $3.7 * 10^{6} \mathrm{~m}^{3}$, corresponding to a sediment yield of $43 \mathrm{t} / \mathrm{km}^{2} / \mathrm{yr}$. The SDLF is clearly different from the upper calcitic formation (CF), which is found in the whole lacustrine area and is mainly of detritic origin. The other lake deposits, which are found in the proximal part of the basin, contain sandy layers, making them more resistive. Finally, no thalweg or buried paleochannel is identified within the Sarliève marsh. In the same way, no outlet is clearly imaged in the north. The Sarliève marsh seems to correspond to a rather flat-bottom depression, closed to the north by a rise of the substratum.

This study shows that the combined use of ES and slingram conductivity mapping, supported by information from several boreholes, is well adapted to the study of globally homogeneous fine grained lacustrine sediments, provided that they were deposited in different paleoenvironmental contexts. Owing to their high conductivity, the endoreic deposits, probably formed in brackish to salty restricted waters, were clearly distinguished from the exoreic deposits, mainly of detrital origin.

Acknowledgements. - This work was supported by the French CNRS programme "ECLIPSE". We wish to thank Vincent Pajot and Jérôme Poisson for their contribution to the acquisition of geophysical data. We also thank G. Gougay and J. Poussin who helped with the translation of this text. We are finally grateful to B. Laignel and the two anonymous reviewers for their constructive comments.

\section{References}

Bendjoudi H., Weng P., Guérin R. \& Pastre J.-F. (2002). - Riparian wetlands of the middle reach of the Seine river (France): historical development, investigation and present hydrologic functioning. A case study. - J. Hydrology, 263, 131-155.

Bossuet G., Ruffaldi P., Martin J. \& Choquier A. (1993). - Reconnaissance du contexte géologique et de la nature du remplissage d'un bassin lacustre du Jura méridional. Le lac de Cerin (Ain, France). - Eclogae geol. Helv., (2), 86, 355-376.

Bossuet G., Ruffaldi P., Magny M., Richard H. \& Mouthon J. (1996). Dynamique et approche quantitative des remplissages fini- et postwürmiens du bassin lacustre de Cerin (Jura, France). - Bull. Soc. géol. Fr., (4), 167, 483-494.

Bossuet G., Camerlinck C., Dabas M. \& Martin J. (2000). - Contribution des méthodes géophysiques (électrique, électromagnétique et radar sol) à l'étude des dépressions lacustres. L'exemple du Lautrey (Jura, France). - Eclogae geol. Helv., 93, 147-156.

Bréhéret J.-G., Macaire J.-J., Fleury A., Fourmont A. \& SouliÉ MÄrsche I. (2003). - Indices de confinement dans les dépôts lacustres holocènes de Sarliève (Limagne, France). - C.R. Géosciences, 335, 5, 479-485.
Buoncristiani J.-F., Petit C., Campy M., Bossuet G. \& Richard H. (2002). - Quantification de l'ablation d'un bassin versant marno-calcaire alpin durant le Petit Age Glaciaire par l'étude d'un système lacustre (cas du lac de "Claps" de Luc-en-Diois Drôme, France). - Geodin. Acta, 15, 103-111.

DAS U.C. \& Verma S.K. (1980). - Digital linear filter for computing type curves for the two-electrode system of resistivity sounding. Geophys. Prospect., 28, 610-619.

DerRUAU M. (1949). - La grande Limagne auvergnate et bourbonnaise, Etude géographique. - Thesis, Univ. Grenoble, 545 p.

Dupis A., Bossuet G., Choquier A., De Luca P. \& Macaire J.-J. (1996). Contribution des méthodes électriques de la géophysique appliquée à l'évaluation des bilans sédimentaires. Exemple du bassin du lac Chambon (Puy-de-Dôme). - Géol. Fr., 4, 79-87.

Einsele G. \& Hinderer M. (1998). - Quantifying denudation and sediment-accumulation systems (open and closed lakes): basic conceps and first results. - Palaeogeogr., Palaeoclimatol., Palaeoecol., 140, 7-21. 
Fourmont A. (2005). - Quantification de l'érosion et de la sédimentation dans le bassin de Sarliève (Massif central, France) au Tardiglaciaire et à l'Holocène. Impact des facteurs naturels et anthropiques. - Ph.D. Thesis, Univ. Tours (France), 420 p.

Fournier G. (1996). - Sarliève: un lac au moyen âge. - Association du Site de Gergovie, 11, 2-34.

FrischKnecht F.C., LABSON V.F., SpIes B.R. \& ANDERSON W.L. (1991). Profiling methods using small sources. In: M.N. NABIGHIAN, Ed., Electromagnetic methods in applied geophysics, 2: Applications. - SEG Publishing, 105-270.

Froese D.G., Smith D.G. \& Clement D.T. (2005). - Characterizing large river history with shallow geophysics: Middle Yucon river, Yucon territory and Alaska. - Geomorphology, 67, 391-406.

GACHON L. (1963). - Contribution à l'étude du Quaternaire récent de la Grande Limagne marno-calcaire: morphogenèse et pédogenèse. Unpublished Thesis, Univ. Paris Sud (France), $169 \mathrm{p}$

GAY I. (1995). - Evolution des flux minéraux pendant le Tardiglaciaire et l'Holocène dans un bassin montagneux à roches magmatiques sous latitude moyenne. Le bassin du lac Chambon, Massif central. - Ph.D. Thesis, Univ. Orléans (France), 208 p.

Gourry J.C., Vermeersch F., Garcin M. \& Giot D. (2003). - Contribution of geophysics to the study of alluvial deposits: a case study in the Val d'Avaray area of the River Loire, France. - J. Applied Geophys., 54, 35-49.

Guérin R., PAnissod C., Thiry M., Benderitter Y., TABbagh A. \& Huet-Taillanter S. (2002). - La friche industrielle de Mortagne-du-Nord (59) - III - Approche méthodologique d'étude géophysique non-destructive des sites pollués par des eaux fortement minéralisées. - Bull. Soc. géol. Fr., (5), 173, 471-477.

HiNDERER M. (2001). - Late Quaternary denudation of the Alps, valley and lake fillings and modern river loads. - Geodin. Acta, 14 231-263.

Jeambrun M., Aubert M., Boulller R., Camus G., Cochet A., D'Arcy D., Giot D., Baudry D., Roche A. \& Bonhommet N. (1973). Carte géologique de la France à $1 / 50000$. Notice explicative de la feuille XXV-31: Clermont-Ferrand. 1ère édition. - BRGM, Orléans.
Keller G.V. \& FrischKneCht F.C. (1966). - Electrical methods in geophysical prospecting. - Oxford, Pergamon press, 517 p.

Lenselink G., Kroonenberg S.B. \& Loison G. (1990). - Pleniglacial to Holocene paleo-environments in the Artière basin in the western Limagne rift valley, Massif Central, France. - Quaternaire, 2, 139-156.

Macaire J.-J., Bossuet G., Choquier A., Cocirta C., De Luca P., Dupis A., Gay I., Mathey E. \& Guenet P. (1997). - Sediment yield during Lateglacial to Holocene periods in the Lac Chambon (Massif Central, France). - Earth Surf. Proc. Land., 22, 473-489.

Macaire J.-J., Bellemlih S., Di-Giovanni C., De Luca P., Visset L. \& BERNARD J. (2002). - Sediment yield and storage variations in the Négron river catchment (southwestern Parisian Basin, France) during the Holocene Period. - Earth Surf. Proc. Land., 27, 991-1009.

McNeill J.D. (1980a). - Electromagnetic terrain conductivity measurements at low induction numbers. - Technical note TN-6, Geonics, Mississauga, Ontario, Canada, 15 p.

MCNeILl J.D. (1980b). - Electrical conductivity of soils and rocks. - Technical note TN-5, Geonics, Mississauga, Ontario, Canada, 22 p.

Trément F., Argant J., Bréhéret J.-G., Cabanis M., Dousteyssier B., Fourmont A., Fournier G., López SÁez J.-A. \& Macaire J.-J (2005). - Paysages et peuplement dans le bassin de Sarliève du Néolithique au Moyen Âge (Puy-de-Dôme, France). Eléments pour un nouveau modèle socio-environnemental. In: APDCA, Ed., Temps et espaces de 1'Homme en Société, analyses et modèles spatiaux en archéologie. - Actes de la $X X V^{e}$ rencontre intern. d'archéologie et d'histoire d'Antibes, 485-498.

VERNET G. \& RAYNAL J.-P. (2000). - Un cadre téphrostratigraphique réactualisé pour la préhistoire tardiglaciaire et holocène de Limagne (Massif central, France). - C.R. Géosciences, 330, 309-405. 